\title{
Alternative Dispute Resolution (ADR): A New Key for Implementing Civil Justice in Bangladesh
}

\author{
Md. Habib Alam \\ Barrister -at -Law, Dhaka
}

\begin{abstract}
This paper discusses the emergence of implication and practice of Alternative Dispute Resolution $(A D R)$ for implementing civil justice and to remove suit backlogs in the disputes resolution system of Bangladesh. Bangladesh has rich traditions of common law culture and it reflects in the existing legal system. But due to recent trends of corruption, political deadlocks and some other key obstacles the present mechanism is supposed to unable in resolving a dispute in swift and has been depriving people from the way of implementing and maintaining civil justice. There has seen some objective and subjective factors have led our civil judiciary to a situation where its demerits are ruling over the merits, manifesting in crippling backlogs and delays. This paper highlights on the role of ADR in implementing civil justice, problems and prospects, and statutory provisions of Alternative Dispute Resolution in the trial system. This Article has explored theoretical concerns underlying contemporary appeals to Alternative Dispute Resolution (ADR) in the civil justice system of Bangladesh.
\end{abstract}

\section{Introduction}

Justice delayed justice denied is a much known quotes of William E. Gladstone. Delayed justice even sometimes fails to give proper remedies to a winning party too. Litigation cost in a civil suit is too high in terms of time, money, energy and human expectations. In this context, ADR offers a many advantages through which a dispute of all kinds can be disposed of swiftly and inexpensively. The present judiciary of Bangladesh has caught in a vicious circle of delays and backlog of cases. The backlog of cases is prolonging the whole trial process. As a result the justice seekers are suffering from many hurdles losing their confidence on the judiciary. This process goes on with no apparent remedy in view. Present rate of disposal of cases and backlog is alarming for justice, rule of law and economic development of the country. There are about 3.5 million cases awaiting disposal across the country and these justice seekers are facing harassments amid waiting for disposal of their cases. A fair and right process for resolving disputes is crucial in any civilized society for the purpose of securing and defending rights of its citizens. Civil courts can bring disputes to an end ensure that people can enforce their rights.

\section{Importance of the study:}

A recent judgment of the Supreme Court of India, has observed that Interminable, time-consuming, complex and expensive court procedures impelled jurists to search for an alternative forum, less formal, more effective and speedy for resolution of dispute avoiding procedural claptrap ${ }^{1}$. Alternative resolution of dispute is considered as effective mechanism to the court process to reduce the work load or pressure on the court. Alternative Dispute Resolution is thus an urgent necessity for the present judiciary of Bangladesh. Judiciary of Bangladesh is caught in a vicious circle of delays and backlog of cases. The backlog of cases is prolonging the trial process. As a result justice seekers are suffering from many hurdles losing their confidence on the judiciary. While delay in judicial process causes backlog, increasing backlog puts tremendous pressure on present cases and vice versa. There are about 3.5 million land related cases awaiting disposal across the country and A World Bank survey reveals that most crimes and corruption in Bangladesh take place in land-related services ${ }^{2}$.The justice seekers are facing harassments amid waiting for disposal of their cases. In PN Duda vs. P.Shiv Shankar and others, the Indian Supreme Court stated that-"Justice cries in silence for long, far too long." To remove the weakness of adversary system in Bangladesh, effective measures should be adopted to dispense justice as early as possible. Article 35(3) of our constitution provided for "Right to a speedy and public trial" So to ensure justice for all Alternative Dispute Resolution is the best possible solution in our country. This process can not only support the legal objectives, but also support other development objectives, such as economic and social

\footnotetext{
${ }^{1}$ State Trading Corporation Of ... vs Indian Sugar Mills on 24 April, 2012, by Mr. Justice Sanjay Kishan Kaul, and Mr. Justice Rajiv Shakdher. available at : http://www.indiankanoon.org/doc/136662189/

${ }^{2}$ Digitising country's land management by Shahiduzzaman Khan, available at : http://www.thefinancialexpressbd.com/old/index.php?ref=MjBfMTBfMTBfMTNfMV8xXzE4NjQzMQ
} 
objectives, by facilitating the disputes that are impeding progress of these objectives. That is why a fair process for resolving disputes is crucial in the country for defending rights of its citizens. Courts end disputes ensure that people can enforce their rights. But in most part of the world, the never mounting expense of litigation, congested court schedules, delay in disposal of case have battered the confidence of people in the judicial system and have put question on the system. It is an alternative route to a speedier and less expensive mode of settlement of dispute. Though it is not a compulsory method of settlement but a voluntary and willing way out of the impasse to transform actual and potential disputes into a peaceful and positive process and to create a lively congenial environment, alternative dispute resolution can be developed and initiated as compulsory beside the formal justice system in our country ${ }^{3}$.

\section{Objectives:}

The key research objective of this study is to analyze the prospects of ADR in implementing civil dispute resolution process of Bangladesh. In addition to that the research objectives are as follows:

- To explore the necessity and challenges of Alternative Dispute Resolution in Bangladesh.

- To identify problems and prospects in implementing the ADR in the existing civil trial system.

- To suggest some recommendations to make ADR more effective and acceptable in resolution of dispute.

\section{Research methodology:}

This is a qualitative study. The general methodological approach of this study is grounded on theoretical approach based on data and information systematically gathered and analyzed. Therefore, this methodology will allow the researchers to generate new theory out of initial data, which may also modify or elaborate the existing theory. The study was conducted on the basis of critical analysis of secondary sources of data. In order to collect the secondary data, relevant literature reviews have been made. For secondary data books, journals, news paper clips, published articles, and other available resources were explored on this issue.

\section{Concept of ADR}

1.1 Alternative Dispute Resolution (ADR) - The term 'alternative dispute resolution' or 'ADR' is often used to describe a wide variety of dispute resolution mechanisms that are short of, or alternative to full-scale court processes. ${ }^{1}$ The term can refer to everything from facilitated settlement negotiations in which disputants are encouraged with each other prior to some legal process. It includes dispute resolution processes and techniques that act as a means for disagreeing parties to come to an agreement short of litigation. The name ADR is an outmoded acronym that services as a matter of convenience only. ${ }^{2}$ ADR is a method of disposing of disputes of all kinds between or among parties swiftly and inexpensively, free of legal intervention and restrictions. It typically includes arbitration, mediation, early neutral evaluation and conciliation. The purpose of alternative dispute resolution is not a substitute consensual disposal or adversarial disposal or to abolish or discourage informal mediation or arbitration outside the courts, but to make alternative dispute resolution a part and parcel of the formal legal system, preserving the trial court's statutory authority and jurisdiction to try the cases should ADR fail. Some may view "ADR as part of their profession while others may conclude that ADR, particularly mediation, as a new profession, some may want ADR to be BDR (Better Dispute Resolution), Enhanced Dispute resolution (EDR), Judicially Assisted Dispute resolution (JADR) or IDR (Innovative Dispute resolution) or for convenience, Appropriate Dispute Resolution, as suggested by A J Pirie in his publication-Alternative Resolution: Skills, Science and The Law. ${ }^{3}$

\subsection{Historical Background of ADR}

Throughout the 1970s and 1980s, a range of nontraditional dispute resolution processes evolved under the general umbrella of $\mathrm{ADR}^{4}$ In 1976, the Roscoe Pound Conference, Perspectives on Justice in the Future, brought together judges and lawyers to discuss potential procedural alternatives to adjudication ${ }^{5}$ The conference

\footnotetext{
${ }^{3}$ Political Constitutionalism: A Republican Defence of the Constitutionality of Democracy by Richard Bellamy. Available at : http://m.friendfeed-media.com/3378a4e1b5895d2695de77fb46c0d7278bc308a8

${ }^{4}$ MELISSA LEWIS \& LES MCCRIMMON, THE ROLE OF ADR PROCESSES IN THE CRIMINAL JUSTICE SYSTEM: A VIEW FROM AUSTRALIA 2-3 (2005), available at http://www.doj.gov.za/ alraesa/conferences/papers/ent_s3_mccrimmon.pdf

${ }^{5}$ Laura Nader, Controlling Processes in the Practice of Law: Hierarchy and Pacification in the Movement to Re-Form Dispute Ideology, 9 OHIO ST. J. ON DISP. RESOL. 1, 5-6 (1993). Roscoe Pound delivered a speech to the American Bar Association on The Causes of Popular Dissatisfaction with the Administration of Justice in 1906 on judicial administration. See generally Roscoe Pound, The Causes of Popular Dissatisfaction with the Administration of Justice, in HANDBOOK FOR JUDGES (Kathleen M. Sampson ed., 2004). He claimed that
} 
aimed to highlight ADR's consensual focus as an advantage over crowded courts and litigious citizens. In Bangladesh, dispute resolution outside court is not new. What is new is the extensive promotion and proliferation of ADR models and its increased uses. Bangladesh history of ADR may be traced from two viewpoints-history of informal and quasi-formal ADR and another is court connected ADR under statutory arrangements. During the British period, in 1870, the Panchayat system was introduced to resolve minor disputes within their area. In 1919, Bengal village Self Government Act was introduced and Union courts were set up to resolve disputes locally. Later on Conciliation Court Ordinance 1961 and the Village Court Act of 1976 were introduced and authority was vested on the Chairman of Union parishad to try petty local cases and small crimes committed in their area and take consensual decisions. These were later strengthened in 1985 with additional power to cover women and children's rights. The Family Court Ordinance of 1985 enacted provisions of consensual method to solve disputes. But the habitual lawyers, judges and parties of adversary system fails to get its limit. The core reason is that it is completely a morphological identity, which is different from current system. Incorporation of ADR in special laws started back in 1969 with the Industrial Relations Ordinance which is now amended as Labour Court Act-2006, where it has been provided that disputes between worker and employer may be settled by negotiation and if it fails, then through conciliation. Muslim Family Law Ordinance was enacted with a view to promote conciliation and ensure speedy settlement in a disputes relating to marriage and family affairs. Bangladesh has undertaken major reforms in its arbitration law in the year of 2001 and finally Arbitration Act-2001 was enacted by the Parliament bringing in substantial reforms in arbitration regarding domestic and international disputes. Former Chief Justice of Bangladesh, Mr. Justice Mustafa Kamal said-In Bangladesh ADR started moving its feet on January, 2000. ADR was introduced in Bangladesh by means of annexed judicial settlement pilot project in an effort to decrease delays, expenses and frustrations of the litigants labouring through the traditional trial process. The pilot program began in a collaborative effort with ISDLS ${ }^{4}$ in a series of Bangladesh Legal Studies of California ADR systems. Three Pilot Family Courts were established in the Dhaka judgeship, which exclusively used judicial settlement to resolve family cases including dissolution of marriage, restitution of conjugal rights, dower, maintenance and custody and guardianship of children. Family Court Ordinance, 1985 authorized the trial judge to attempt reconciliation between parties prior to and during trial. The pilot courts were staffed by 30 Assistant judges selected from all over Bangladesh. All three pilot programs were fully functioning by January 2001. Once judges had begun successfully settling cases, the program was expanded slowly to additional courts throughout the country. By the end of first year of program, the number of pilot family courts increased into 16 in 14 districts of Bangladesh. As a result in 2003, the Code of Civil Procedure was amended to introduce mediation and arbitration through section $89 \mathrm{~A}$ and $89 \mathrm{~B}$ as viable means of dispute resolution in non-family disputes. In addition to this amendment, the Money Loan Court Act, 2003 stipulated the rule of judicial settlement, enforces for money loan recovery cases. The Civil Courts started mediation in non family disputes from $1^{\text {st }}$ July, 2003 and by further amending the Code of Civil Procedure, 1908, mediation has been extended to appeal cases through section 89C from $1^{\text {st }}$ July, $2006 .^{5}$

1.3 Mechanisms of ADR- Negotiation, mediation, conciliation and arbitration are the most common features of ADR technique in Bangladesh.

1.3.1 Negotiation- It is "mutual decision and arrangement of the terms of a transaction or agreement." Bargaining is a common feature of the negotiation process. It provides the parties or disputants an opportunity to exchange ideas, identify the irritant point of differences, find a solution and get commitment from each other to reach an agreement. There is no third party who facilitates the resolution process. It is different from mediation and arbitration.

1.3.2 Mediation- Mediation is voluntary and informal process in which the disputing parties select a neutral third party (one or more individuals) to assist them in reaching a mutually acceptable settlement. In other words, it is a process to try to get agreement between two or people or groups who disagree with each other. ${ }^{7}$ It is simply an extension of the negotiation process. Mediators are individuals experienced in the negotiation process who bring disputants together to work out a settlement which both parties can accept or reject. The mediator has no advisory or determinative role in regard to the content of the dispute or the outcome of its resolution, but may advise on or determine the process of mediation whereby resolution is attempted.

the Anglo-American legal system was plagued with an "individualist spirit," a focus on litigation as a "game," a belief in judicial supremacy, a lack of legal philosophy to motivate the legislature to reform the law, and uncertain case law. Id. at $149-50$. 
1.3.3 Conciliation- Conciliation is another common form of dispute resolution. In this process a third party meets separately with the disputants in an effort to establish mutual understanding of the underlying causes of the dispute and thereby promote pacific settlement. ${ }^{8}$ The conciliator may advise on or determine the process of conciliation whereby resolution is attempted, and may make suggestions for terms of settlement, give expert advice on likely settlement terms, and May actively encourage the parties to reach an agreement.

1.3.4 Arbitration- Arbitration is a process by which a dispute between two or more parties is submitted to a panel of impartial third parties for resolution on the merits based on the evidence presented at a hearing. Arbitrators are professional and business people who are selected by the court to assist in the informal resolution of disputes because of their knowledge, expertise and reputation for fairness and impartiality. It is pertinent to mention here that the arbitrators does not exercise a judicial function in course of inquiry or investigation as to the amount of compensation and as such is not a court although he is expected to act within judicial norms. ${ }^{9}$

1.4 Advantages of ADR- Alternative dispute resolution is that mechanism which resolve disputes more efficiently and amiably by finding self-made process best suited to the parties. It is the method where the disputants can participate in the solution finding process. ADR cannot be substitute of formal judicial system, but can complement and support it. Advantages of this process are enormous:

- Win-Win outcome;

- Social groups that are not adequately or fairly served by the judicial system can have access to justice through ADR mechanism, as it provides legal advice to members of disadvantaged groups on whether and how to use the court system;

- In most of the cases, the rate of success is high as it can bring a satisfactory solution among the parties to the dispute. Since the process is determined and controlled by the parties, it is considered as more flexible than formal litigation;

- It can reduce delay in the resolution of disputants and increase disputant's satisfactions;

- ADR process can effectively reduce the cost of resolving disputes;

- It manages disputes and conflicts that may directly impair development initiatives;

- It helps to reduce pressure on judiciary.

1.5 Disadvantages of ADR- Since there is many success stories of resolving disputes through ADR process, there is still some drawbacks due to which people frequently go to legal processes. Those can be identified as following:

- ADR programs do not work well in the context of extreme power imbalance between the parties;

- ADR programs do not set precedent, define neither legal norms nor do they promote a consistent application of legal rules;

- Sometimes people faced with biased decisions;

- Some are interested in legal solution;

- Lack of proper guidelines relating to mediation;

- Lack of sufficient budget and absence of separate institution;

- Little scope for client to client interaction which hinders potentiality for alternative dispute resolution;

- Persons dealing with ADR do not have adequate knowledge and experience;

- Inadequate administrative and logistic support system, enormous work-load of the judges, poor salaries and poor working conditions-all having negative impact on the initiative and efficiency of the judges;

- It is inappropriate to use ADR to multi-party cases in which some of the parties or stakeholders do not participate;

- In some types of disputes ADR method is not at all appropriate for example in cases of systemic injustice, discrimination or violation of human rights etc.

1.6 Necessity of ADR in Bangladesh- Justice delayed is justice denied is a very common adage in the judicial domain. It is one of the most burning problems in the administration of justice in Bangladesh. This system of justice is so ambiguous and miserable for the mass people that it cannot be explained in a word. There are many instances that poor people who went to court to address their grievances after selling off their lands and property to meet the expenses of the court, but did not get justice in their lifetime. At present the only demand of mass people is the speedy approach to justice. Focusing on the experiences of some other countries including the USA and with optimistic view that our age-old culture provides to settle any disputes through mediation, a carefully devised mechanism which involves proper court administration, effective case management and amicable consensual dispute resolution, can revolutionize our entire civil justice delivery system. The essence of the concept is that after filing of the plaint and submission of the written statement, attempts would be made to 
resolve the dispute through various forms of alternative dispute resolution (ADR) by early judicial intervention. In PN Duda vs. P.Shiv Shankar and others, the Indian Supreme Court stated that-"Justice cries in silence for long, far too long." 10

To remove the weakness of adversary system in Bangladesh, effective measures should be adopted to dispense justice as early as possible. Article 35(3) of our constitution provided for "Right to a speedy and public trial" So to ensure justice for all Alternative Dispute Resolution is the best possible solution in our country. This process can not only support the legal objectives, but also support other development objectives, such as economic and social objectives, by facilitating the disputes that are impeding progress of these objectives.

\subsection{Practice of ADR through Statutory Provisions in Bangladesh-}

The Code of Civil Procedure, 1908- The Code of Civil Procedure was amended in 2003 (Act IV of 2003) to introduce mediation under section 89A, arbitration under section 89B and mediation in appeal under section 89C. All these mechanisms are court-annexed and were made applicable in all kinds of non-family litigations. Section 89A provides for mediation at pre trial stage whereas arbitration may be resorted at any stage of litigation.

Mediation in appeal is provided under 89C, under which an Appellate Court may mediate in an appeal or refer the for mediation in order to settle the dispute or disputes in that appeal, if the appeal is an appeal from original decree under Order XLI and is between the same parties who contested in the original suit or the parties who have been substituted for the original contesting parties. The provision is non doubt unique but unfortunately the Appellate Courts are not found so vigilant to implement the same let alone the parties to the appeal.

Muslim Family Law Ordinance, 1961- Under the Muslim Family Law Ordinance, 1961 provision for reconciliation through arbitration council which is not a part of judicial ADR but administrative in nature has been provided for in three circumstances.

(I) In case of polygamy under section 6;

(II) In case of dissolution of marriage (divorce) and making it effective under section 7;

(III) In case of failure of the husband to provide maintenance of his wife under section 9 .

(IV)

Customs Act, 1969 ( act IV of 1969)- The said act was amended by Finance Act, 2011 (act XII of 2011) and thereby included chapter XVIIIA under the caption Alternative Dispute Resolution covering section 192A to 192K, which brought new dimension in our international export and import.

Income Tax Ordinance, 1984- By Finance act, 2011 a ground backing change made in the Income Tax Ordinance, 1984 by incorporating chapter XVIIIB under the caption Alternative Dispute Resolution including section $152 \mathrm{~F}$ to $152 \mathrm{~S}$.

Family Court Ordinance, 1985- Family Court Ordinance provides for a mechanism for reconciliation through judges as a necessary part of judicial proceedings (court -annexed ADR). It has built in conciliation mechanism enabling disputant parties to resolve the outstanding issue informally, inconspicuously and with a sense of accommodation in which the family Courts play the role of a well -wisher and friend rather than adjudication. The role of the family judge is of vital importance for attempting such reconciliation between the parties. ${ }^{11}$ Two types of court-annexed reconciliation proceedings are envisaged in the ordinance-

(I) Pre-trial reconciliation proceedings under section 10; and

(II) Post-trial reconciliation proceedings under section 13

In fact the enactment of the family Court system was rooted in a social welfare philosophy to establish a link between the legal and social sciences. But these provisions have not been properly understood and practiced so far. ${ }^{12}$

Value Added Tax act, 1991 (act XXII of 1991)- By Finance Act under section 41Ka to 41ta the procedure of ADR was incorporated that brings new phenomenon in our Revenue Law.

Arbitration Act, 2001- In Bangladesh the Arbitration Act of 1940 was in force until 2001 when the Arbitration Act, 2001 was enacted. As the act of 1940 causes much delay in settlement of disputes between parties in law courts, which prevented investment of money in Bangladesh by other countries. So Bangladesh has taken major reform in this regard and finally in 2001 the Arbitration Act, 2001 was enacted by the Parliament bringing in substantial reforms in arbitration, regarding domestic and international disputes.

Money Loan Court Act, 2003- The Money loan Recovery Act (Artharin Adalat Ain, 2003) was enacted in 2003 within built provisions for ADR. The process is settlement conference to be presided over by a trial Judge and to be held in camera. The proceedings are confidential. As this method proves ineffective so the present 
government amended the law in 2010 (Act XVI of 2010) and included mediation in place of settlement conference. Thereby new provisions were incorporated under section 22 and 23 of the Loan Recovery Act, 2003. Section 38 of the amended act provides the parties to mediate the case even at the execution stage. Section 44 Ka provided that ADR may be made during appeal and revision stage.

Labour Law, 2006 The first legislation where the concept of ADR in the form of negotiation and conciliation has been effectively introduced and recognized by law is in the field of labour law, namely Industrial Relations Ordinance, 1969 which is now replaced by the Labour Act, 2006. This Code being both social and legal legislation envisages two different approaches to dispute resolution'

(I) pure legalistic approach to individual employment dispute; and

(II) Socio-legalistic approach to industrial dispute.

Village Court act, 2006 and Conciliation of Disputes (Municipal Areas) Act, 2004-The adjudication process of both the laws are based on informal traditional shalish system which is considered as ADR. Unlike formal judicial adjudication, the Village Court and Board of Conciliation are not required to follow the law of evidence and other procedural law. As a result, there does not seem to have any problem of providing easy and speedy rural justice by these forums and as such they may be viewed as forums of ADR.

1.8 Problems of ADR in Bangladesh- Though ADR mechanism have been initiated in our civil laws but result is beyond expectation. There exists lot of reason for which Alternative Dispute Resolution fails to become a success. Among those following are mentionable-

i) Application of ADR method is not mandatory;

ii) Parties to the suit have no interest for ADR;

iii) Absence of specific guideline to apply this mechanism;

iv) Absence of skilled and trained mediator;

v) Lack of sufficient budget, distinct policy for this issue and absence of particular institution for training on ADR by the government.

vi) Decisions are not legally binding;

v) Litigants are interested in court proceedings;

vi) It cannot be a substitute for a formal judicial system.

\section{Conclusion and Suggestions-}

Delay in disposal of cases become common culture in our court system. Now days it become a factor of injustice, a violator of human rights. People are getting frustrated while they are filing a suit before the court as they are uncertain about when they will see the end of the disputes. But it cannot be ignored that every litigants have right to speedy and fair trial. Alternative dispute resolution mechanism has the potentiality to manage a case without causing delays and financial loss to the parties. In an effort to streamline the life of a case while preserving justice, alternative dispute resolution (ADR) offers an arena for litigation outside of the trial process. We can take the examples of developed countries like UK and USA where due to initiation of ADR mechanism at trial system they are getting success while dispensing justice. So to ensure justice for all ADR mechanism can be practiced as mandatory as it does not hamper human rights. But to get the full benefit of this mechanism, it must be free from any kind of biasedness.

To make ADR more effective, extensive and pro-active, co-ordination is needed among different agencies. Following initiatives can be given to apply ADR mechanism in full swing in our legal system:

1. Creating awareness about ADR;

2. Spreading the success story of ADR;

3. View ADR as an addition to not a replacement of the litigation system.

4. Case management should be observed ;

5. Bringing change in court infrastructure;

6. Including stakeholders in court reforms;

7. Involving the Bar Association in ADR;

8. Providing training for mediators;

9. Reform in civil justice system;

10. Judges can actively and persistently suggest ADR options;

11. Particular institute can be formed for training of mediation;

12. The court can play a vital role by educating;

13. Reforming Village Court by initiating ADR in place of shalish 


\section{Reference}

[1]. Law, justice and parliamentary affairs minister Barrister Shafique Ahmed on inaugural session of a training course on ADR for the judges and lawyers at Judicial Administration Training Institute in Dhaka on $16^{\text {th }}$ July, 2011.

[2]. ADR in Bangladesh by Mr. Justice Mustafa Kamal, former Chief Justice of Bangladesh in a presentation on ADR, invited by the Supreme Court of Pakistan.

[3]. Alternative Dispute Resolution practitioners guide, March 1998, Centre for Democracy and Governance, Technical Publication Series, page-4.

[4]. Thomas J. Stipanowich, ADR and the "Vanishing Trial"-The Growth and Impact of "alternative Dispute Resolution", Journal of Empirical Legal Studies, Volume 1, Issue 3, 843-912, November 2004 at page 845.

[5]. Former Chief Justice of Bangladesh speech given at the South Asian Regional Workshop on ADR organized by the British Council, on $7^{\text {th }}-8^{\text {th }}$ March, 2004 .

[6]. Pirie A J, Alternative Resolution: Skills, Science and the law.

[7]. Jean R. Sternlightm, Is Binding Arbitration a Form of ADR? An argument that the Term ADR has begun to outline its usefulness, 2000, J. Disp. Resol,97

[8]. Former Chief Justice Mustafa Kamal, in a presentation on ADR, invited by the Supreme Court of Pakistan.

[9]. Ahmed.Azim .Ishrat \& Karim Ershadul, Principles of Civil Litigation- Bangladesh Perspective, first edition, Law Lyceum.

[10]. Taslima monsoor, Women and development of Family Law; a step Towards Right Direction? Bangladesh journal of Law. BILIA, Vol-1 no.2 December, 1997.

[11]. Naima Huq, Divorce Conciliation, the Dhaka University Studies, Part F, The journal of the Faculty of law, vol-12, no-1. 